\title{
Do + subjunctive, future reference and modality in Albanian
}

\author{
Ardita Berisha $^{\text {a (D) Kadire Binaj }}{ }^{\mathrm{b}} *$ \\ ${ }^{a}$ Department of Albanian Language, Faculty of Philology, University of Prishtina 'Hasan Prishtina', Str. George Bush, no. 31,10000, \\ Prishtinë, Republic of Kosovo
}

\section{APA Citation:}

Berisha, A., \& Binaj, K. (2019). Do + subjunctive, future reference and modality in Albanian. Journal of Language and Linguistic Studies, 15(4), 1426-1435.

Submission Date:22/08/2019

Acceptance Date:08/10/2019

\begin{abstract}
The purpose of this paper is to present the use of the structure $d o+$ subjunctive, as one of the grammatical forms that marks futurity in Albanian. This grammatical form has derived from the free syntactic structure of $d u a+$ subjunctive, which used to express modality of desire or volition; therefore, $d o+$ subjunctive in Albanian is known as volitive future. In addition to its main function, namely reference to future time, $d o+$ subjunctive is also often used to express clear modal meaning. This modal meaning that characterizes $d o+$ subjunctive can be read in a variety of ways, depending on the context in which it appears. It can be used to express an epistemic conclusion, a conclusion based on speaker's general knowledge or experience. This grammatical form can also be used to express different forms of deontic modality such as an order or a promise. Though less commonly, do + subjunctive can also be used to express speaker's volition or desire. This modal component is characteristic especially for the $d o+$ imperfect subjunctive: do të punoja "I would work". In addition to these uses, $d o+$ subjunctive can also be used in conditional constructions, both in apodosis and protasis, to express real and unreal conditions.
\end{abstract}

(C) 2019 JLLS and the Authors - Published by JLLS.

Keywords: futurity; tense; modality; epistemic; deontic; dynamic; conditional

\section{Introduction}

The purpose of this paper is to present the use of $d o+$ subjunctive in Albanian, its time reference and the modal meaning it can express depending on the context in which it is used. This form is known in Albanian as the form of the future, and is treated within the category of tense (ASHSH, 2002; Demiraj, 1988; 2002; Topalli, 2012). In the Grammar of the Academy (2002), do + subjunctive is nowhere treated as a modal form in present-day Albanian. According to these authors, this form has neutralized its modality, therefore now is used to express futurity. In Albanian, do + subjunctive has generalized the modality of volition it originally had, but still expresses prediction or plan for future situations. Therefore, in this sense it is still modal; it is only that in that use the reference to future time is also emphasized. In various contexts it may also express emphasized modal meanings. Based on the research

\footnotetext{
${ }^{*}$ Corresponding author. Tel.: +377 45294407

E-mail address: kadire.binaj@uni-pr.edu
} 
done, its futurity use constitutes about $81.52 \%$ of the cases, while modal functions about $18.47 \%$ of the cases.

\subsection{Literature review}

Until recently, $d o+$ subjunctive in Albanian has been considered as a tense form that marks futurity (Demiraj, 1988, 2002; ASHSH, 2002; Topalli, 2012.). According to these scholars, do + subjunctive has neutralized its modal meaning and has become a future form. Its modal component has been only rarely and superficially discussed. The use of $d o+$ imperfect subjunctive, or $d o+$ past perfect subjunctive in a conditional function, has been considered as conditional mood (ASHSH, 2002; Breu, 2010) or volitive mood (Breu, 2010). The future form, since it derives from a free structure which once had modal meaning, based on the contexts in which it is used, can often express its modal meaning clearly. Depending on the context of use different types of modalities can be expressed.

Given that in the futurity use there is always a component of prediction or planning, in this paper $d o$ + subjunctive will be treated as epistemic futurity. Alongside its function as epistemic futurity the modal functions of $d o+$ subjunctive will be presented, together with other analogous forms. These uses do not present different moods in Albanian, but merely uses of different functions of the same form.

\subsection{Research questions}

- What are the uses of $d o+$ subjunctive in the selected corpus?

- What is the main use of $d o+$ subjunctive?

- Is $d o+$ subjunctive used only to express reference to future time or is it used to express other modality meanings as well?

- What are the most frequent uses of $d o+$ subjunctive?

- What kind of modal meanings does $d o+$ subjunctive express?

- How does $d o+$ subjunctive express conditional meaning?

\section{Do + subjunctive form}

Do + subjunctive is a grammaticalized form in Albanian, whose main function is to express futurity. As in other Indo-European languages, in Albanian the grammatical form do + subjunctive, which expresses futurity, has evolved from the free syntactic structure with modal meaning of volition or desire, dua + subjunctive (Bokshi, 2012; Demiraj, 1988). The first element of this analytical form, namely do, derives from the verb dua, which is now fossilized, whereas grammatical markers of person, number, tense, and voice are taken by the verb in the subjunctive form, thereby the whole structure functions as a grammaticalized form. Given that do + subjunctive has for some time preserved its modal meaning, it is still known as volitive future (Demiraj, 1988; Topalli, 2012).

Although due to the generalization of its initial modal meaning and its emphasis to future time reference, do + subjunctive has shifted to a marker of futurity, it often tends to present clear modal meanings. Bybee et al. (1994, p. 3) states that markers of futurity (she calls them morphemes) tend to be modal due to the specific lexical sources out of which they develop and the interferences available in the contexts in which they are used. Therefore, since do + subjunctive derives from a free modal structure (dua + subjunctive), in certain contexts it can often express different types of modalities. In addition, the tendency of this future form to be modal has to do also with the very concept of futurity: the expression of non-factuality. When talking about future situations, one cannot be neutral; but one's 
attitude, will also be expressed to the expected situations. According to Lyons (2001, p. 286) precisely these two characteristics of the future make the latter occupy an intermediate position, between tense and modality. Likewise, Lyons claims that the future includes the intertwining of both categories, as much as it deals with time, it deals also with modality.

In Albanian, besides $d o+$ present subjunctive, there are other forms where this verbal particle is related to the main verb in the imperfect (the future of the past), in the past (future perfect) and in the past perfect of the subjunctive (future perfect of the past) (ASHSH, 2002, pp. 316-318):

$\begin{array}{cc}\boldsymbol{d o}+\text { present subj. } & \boldsymbol{d o}+\text { imperf. subj. } \\ \text { do të punoj } & \text { do të punoja } \\ \text { "I will work" } & \text { "I would work" } \\ \text { do + past subj. } & \boldsymbol{d o}+\text { past perfect subj. } \\ \text { do të kem punuar } & \text { do të kisha punuar } \\ \text { "I will have worked" } & \text { "I would have worked" }\end{array}$

Given this, these analogous forms present four-fold temporal opposition within the futurity. In addition to tense differences, they also show modal differences.

\subsection{The use of do + subjunctive}

\subsubsection{The use of $\boldsymbol{d o}+$ subjunctive as a reference to predicted/planned situation in the future}

In its most common use, $d o$ + present subjunctive (do të punoj "will work") is used to refer to a predicted or planned situation in the future. While $d o+$ subjunctive denotes a planned situation, it also implies a degree of speaker's certainty with regard to the planned situation. Therefore, this verbal form marks an epistemic future in Albanian language:

(1) Sot do të shpallet dhe do të betohet qeveria e re e kryeministrit Samarus.

Today, the new cabinet of the Prime Minister Samarus will be announced and will be sworn.

This verbal form, although epistemic, differs from its other modal epistemic uses because in this use it emphasizes reference to future time.

\subsubsection{An epistemic conclusion}

There are, however, several contexts in which different elements with either strong or weak degree of modal meaning can be identified. Its use as strong epistemic modality presents one of these uses. In such cases, it can be used to express future reference for all three persons:

(2) Posa u nisën të gjithë bashkë. Në mbrëmje do të jenë (jemi/jeni) në shtëpi.

"They have just left all together. In the evening they (we, you) will be home."

Its use implies the fact that the expectation of the speaker for the actualization of the future situation is based on some common sense or general knowledge of that speaker: by knowing the time and place of their departure the speaker comes to the conclusion about the time when they will arrive home. Thus, $d o+$ subjunctive expresses speaker's certainty in what he is saying. According to Palmer (2001, p. 34), "such certainty is the result of common thinking, namely thinking based on the speaker's common experience".

Therefore, the use of $d o+$ present subjunctive as epistemic modality relates to speaker's expectations or prediction of the situation based on his knowledge or experience. Such a conclusion Palmer (2001, p. 6) considers as a reasonable or an assumptive conclusion. In such contexts in Albanian language, duhet + present subjunctive is not appropriate, although it can be used as epistemic: 
*Posa u nisën të gjithë bashkë. Në mbrëmje duhet të jenë (jemi/jeni) në shtëpi.

*They have just left all together. In the evening they (we, you) must be home.

While do + present subjunctive is used to express speaker's expectation or belief, characterized with high degree of certainty (the speaker relies on some general knowledge), duhet + present subjunctive is used to express conclusions based on available evidence, either explicit or implicit (for corresponding structures in English, see Palmer, 2001; Huddleston \& Pullum, 2002). Therefore, although both structures are used in epistemic function, duhet is stronger than do.

Do + present subjunctive presents a typical structure when it comes to expressing reference to future time. Nevertheless, at times, it can also be used to express reference to present time, always conveying its assumptive character. Thus, even when it expresses reference to present time, it still preserves the contrast with $d u h e t+$ present subjunctive:

(3) a) Shiko se do të jetë brenda diku (I have invited him).

"Look! He will be somewhere inside" (I have invited him)

b) Shiko se duhet të jetë brenda diku (I saw him earlier).

"Look! He must be somewhere inside" (I saw him earlier).

In this epistemic function, $d o+$ past subjunctive can also be used, expressing speaker's conclusion with a high degree of certainty. The situation expressed refers to the present time:

(4) Tashmë do të jenë mbledhur të gjithë.

"They must have gathered by now."

\subsubsection{The dynamic modality use of do + subjunctive}

Though less commonly, $d o+$ subjunctive can be used to express volition or desire of the speaker or a certain person. This is evident considering the fact that this grammatical form has derived from the free syntactic structure $d u a+$ subjunctive. Thus, in subordinate conditional clauses, as in the example (5) below, the condition relates to the desire of the speaker, and therefore in this case $d o+$ subjunctive relates to other contextual elements as well.

In this modal sense, it is $d o+$ imperfect subjunctive, namely the future of the past, that is used the most. It can be used to express the volition or desire of the speaker towards a future situation, especially in conditional constructions:

(5) Nëse është sipas dëshirës, unë megjithatë do ta merrja Orestin.

"If I had to choose, I would again take Orest."

In such uses, $d o+$ imperfect subjunctive shifts forward in time, from the future of the past, i.e. from the past, it shifts to the future. Such a shift is characteristic to the grammatical form at issue when used in conditional constructions.

The example below illustrates the use of $d o+$ imperfect subjunctive in the function of volitive modality, expressing reference to the future in the past. The expressed situation belongs to the past, but the volitive modality, of course, belongs to the moment of speaking (6). The volitive modality may belong to the past only when it is reported; in such cases the lexical verb would be used instead (7):

(6) Do të shkoja qysh atë ditë dhe do të qëndroja më gjatë, por nuk mund të merrja pushim.

"I would go there that very day and would stay longer, but I could not take a leave."

Compare:

(7) Unë doja të shkoja qysh atë ditë dhe doja të qëndroja më gjatë, por nuk mund të merrja pushim. 
"I wanted to go there that very day and wanted to stay longer, but I could not take a leave."

\subsubsection{The deontic modality use of do + subjunctive}

Do + subjunctive can also be used to express an order (8) or to convey a promise (9), ie different types of directives. In this use, there is an external deontic source (or authority), usually the speaker, who gives an order to the recipient or makes a promise to him. Thus, as Palmer (2001, p. 69) states "the characteristic of deontic modality is that the conditioning factors (ordering the person indicated as the subject or making a promise to him) are external". In these modal functions, $d o+$ subjunctive is less commonly used:

(8) Do të niseni tani!

"You will leave now!"

(9) Zotëria shtatlartë me faqe të kuqe, i cili gjithë kohën heshtte dhe më maste, drejtori i Paramountit për Britaninë e Madhe, për herë të parë m’u drejtua: - Librin e xhirimit e ka shkruar Majkëll Hejsting, fitues i Osakrit për skenarin e filmit Oliver Tuisti. Do të vini në Londër. Do ta keni lektorin më të mire. Do t'i keni kushtet maksimale për punë - përfundoi dhe ma dha librin me kopertina të gjelbërta, me shkronja të zeza The Adventures. Po, nëse do të më pëlqejë roli, përsërita dhe kërkova ndjesë, sepse ekipi po më priste.

"The tall blushing man, who was silent all the time while gazing at me, the Paramount director of the Great Britain, for the first time said to me: The screenplay has been written by Michael Hastings, Oscar winner for the screenplay of the Oliver Twist movie. You will come to London. You will have the best editor. You will have the best working conditions - and gave me the green-covered book with The Adventures written in bold. Yes, if I like the role, I replied and apologized, as the team was waiting for me."

The first example (8) illustrates the strength of modality of $d o+$ subjunctive to express a strict order, whereas in the second example (9) its strength of modality weakens and thus only the speaker's promise is expressed.

\subsubsection{The conditional use of $d o+$ subjunctive}

Do + present subjunctive can appear in conditional constructions, namely in conditional apodosis and protasis. Since it expresses future time reference, it is used in conditional structures that express open conditions (as in the example below):

If + present, indicative $-d o+$ present subjunctive

(10) Nëse përparojmë në La Liga, atëherë kjo do të na shërbejë dhe do të na ndihmojë në Kupën e Spanjës dhe në Ligën e Kampionëve.

"If we do well in La Liga, then this will be useful and will help us in the Spanish Cup and the Champions League."

In the Grammar of the Academy (2002) and in other studies (Breu, 2010; Camaj, 1984) do + imperfect subjunctive (do të punoja "I would work") and past perfect subjunctive (do të kisha punuar "I would have worked") are considered forms of conditional mood. These future forms, when used in the conditional function, emphasize their conditional meaning. However, in Albanian there are numerous of other grammatical forms that can be used in the conditional function: the indicative, the subjunctive, the imperative, etc.:

Nëse shkon ti, shkoj edhe unë.

"If you go, I'll go too."

Po shkove ti, shkoj edhe unë. 
If you go, I'll go too.

Nëse ke dicka për të thënë, urdhëro.

If you have something to say, say it.

Therefore, in Albanian the modality of condition can be expressed by different conditional constructions, formed by conditional conjunctions which combine with different moods and tenses. But there is no grammatical marker that marks the conditional mood. Consequently, the structures do të punoja "I would work" and do të kisha punuar "I would have worked" are future forms that are used also in a conditional function.

The characteristic of $d o+$ imperfect subjunctive, as noted above, is that it can shift in time, changing the time reference from past (more specifically, from the future of the past) into the future:

Do + imperfect subjunctive - po + imperfect, subjunctive

(11) Ajo do të shkonte atë ditë, po t'i bashkoheshe edhe ti, por, ti as nuk deshe ta dëgjoje.

"She would go that day if you joined her, but you did not even want to hear about it."

Do + imperfect subjunctive $-p o+$ imperfect, subjunctive

(12) Unë do ta tregoja të vërtetën, po të më mbronte ligji, përndryshe nuk mund të rrezikoj as veten, dhe as familjen time.

I would tell the truth if the law protected me, otherwise I can neither risk myself nor my family.

In the first sentence (11), do të shkonte "would go" is used to express time reference for a certain moment in the future of the past, meaning that at the moment of speaking a closed condition is expressed. On the other hand, in the second sentence (12), although the form is the same, it expresses time reference starting from the moment of speaking towards the future, meaning that there is an open condition expressed. In terms of the modal aspect of factuality, they differ in that one represents a real fact, and the other an unreal one. Thus, in the first sentence (11), which refers to the past, the fact is known, a factual situation is expressed: it is implied that she did not go there, since he did not join her; in the second (12), which refers to the future, the fact is still unknown; it is unreal.

Do + past subjunctive (do të kem shkuar "will have gone") is used to express the possibility of actualizing the situation if the condition is fulfilled. It expresses past time reference (do të kenë arritur $n \ddot{~ k o h e ̈ ~ " w i l l ~ h a v e ~ a r r i v e d ~ i n ~ t i m e ") . ~ F r o m ~ t h e ~ p r e s e n t ~ p o i n t ~ o f ~ v i e w, ~ a ~ c l o s e d ~ c o n d i t i o n ~ i s ~ e x p r e s s e d, ~}$ nonetheless, one is left to infer whether the condition is fulfilled or not. Therefore, there is still no confirmation for the fulfillment of the condition or the lack thereof. As a result, even in terms of factuality, it expresses a situation still unknown:

Do + past subjunctive - if + past, indicative

(13) Ata do të kenë arritur në kohë, nëse i janë përmbajtur udhëzimeve tona, - i tha ai.

"They will have arrived in time if they followed our instructions, he said."

Do + past perfect subjunctive (do të kisha punuar - would have worked) can be used in the apodosis and protasis of the conditional construction. In the example below (14), in the protasis of the conditional construction, it expresses an unfulfilled condition in the past, i.e. a closed condition. In apodosis it expresses a hypothesis that (at the moment of speaking) is practically impossible:

Do + past perfect subjunctive - if + future perfect of the past

(14) Ata do të kishin kontribuar shumë në këtë çështje, nëse do të kishin qenë të pranishëm.

"They would have contributed significantly to the issue at hand if they had been present." 


\section{Methodology of research}

In this paper, the descriptive, analytical and empirical, comparative, and theoretical and interpretive methods have been applied. The analysis that characterizes the paper is more of a qualitative nature and less of a quantitative one. Statistics are only given to show how often $d o+$ subjunctive expresses clear modal functions (epistemic, dynamic, deontic, and conditional) as opposed to its use as a future form, with emphasized time reference, whilst denoting rather generalized modal meaning.

First, the theoretical background is presented in which the current discussions with regard to this form have been reviewed. According to these studies, in Albanian this form has generally been considered as a marker of futurity. However, the said studies do not address its specific modal uses; on the contrary, they have been discussed only superficially.

On the other hand, in this research, unlike previous studies, $d o+$ subjunctive has been analyzed in a pragmatic viewpoint. Based on the analysis of the use of $d o+$ subjunctive in the selected corpus, we have identified marking of the future as its main function; besides this function, other uses in which $d o$ + subjunctive expresses clear modal meanings have also been identified.

To extract these data, all the clauses in the corpus where $d o+$ subjunctive and other analogous forms appeared have been analyzed. In some cases, in order to clearly see its modal meaning, the sentences are analyzed within a broader context (for example, we need context to analyze the use of do+ subjunctive as deontic modality, as a permission or as an order. Likewise, a broader context is needed in order to understand the temporal reference of the future or the future in the past expressed by $d o+$ imperfect subjunctive in conditional apodosis).

The selected corpus consists of different types of texts. The texts were selected randomly, thus reflecting the use of this particular form in present-day Albanian. The corpus is composed of literary and non-literary texts. Such selection gives a more complete picture of its use in present-day Albanian. The texts that make up the corpus include two novels of Bekim Fehmiu (2011, 2016), one volume of the daily newspaper "Koha Ditore" (2012) and data extracted from the Albanian National Corpus.

The findings of the selected corpus present a comprehensive view of all possible uses of $d o+$ subjunctive and other analogous forms in Albanian. Unlike earlier studies in Albanian language, in this paper $d o+$ subjunctive is not considered a category of tense, but rather a modal marker: 1 . The use of $d o+$ subjunctive as epistemic future, in which case future references are emphasized and a predicted or

a planned situation of the future is expressed 2. the use of $d o+$ subjunctive with clear modal meanings (epistemic, deontic, dynamic). The $d o+$ subjunctive has not been previously analyzed in the pragmatic aspect. Finally, this research, having a different approach, brings new insights and presents a novelty for the studies of this kind in the Albanian language.

\section{Results and discussion of findings}

As stated at the beginning, the purpose of this paper was to address one of the grammatical markers of volitive future in Albanian, $d o+$ subjunctive. The distribution of this future form (including other analogous forms) was discussed and both the modal meanings and time reference that it expresses were analyzed.

Upon completion of the research, we have come up with the following results:

Having analyzed the corpus, $d o+$ subjunctive has two main uses:

1. It is used to mark predicted or planned future with neutral modal meaning and emphasized temporal meaning. In this function, $d o+$ subjunctive is used in $81.52 \%$ of the cases. 
2. It is used to mark clear modal meaning. In this function, $d o+$ subjunctive is used to express clear modal content, unlike the first use where the modal component is neutralized. This function is found in $18.47 \%$ of the cases.

Therefore, $d o+$ subjunctive, in addition to its primary function to refer to a future situation, i.e. the function of a marker of futurity: Sot do të shpallet dhe do të betohet qeveria e re e kryminstrit Samarus. "Today, the new cabinet of the Prime Minister Samarus will be announced and will be sworn.", - is also used to express clear modal meaning. Thus, $d o+$ present subjunctive or $d o+$ past subjunctive are used to express epistemic modality; these forms usually express future time reference, although they may sometimes express present time reference. This function of the above-mentioned forms denotes assumptive conclusions of the speaker - conclusions about which the speaker relies on general knowledge or experiences, namely on his common thinking. Do + present subjunctive is rarely used to express volitive modality or deontic modality: permission or promise. In both these functions, do + present subjunctive is used. On the other hand, $d o+$ imperfect subjunctive (future of the past) is usually used to express temporal references of the future in the past. All these forms have wide distribution in conditional constructions, being used in apodosis and protasis. The $d o+$ imperfect subjunctive form (future of the past) is characteristic since it can be used to express unreal possibilities: Po të më ftonte atë ditë, do të shkoja edhe unë "If he invited me that day, I would go", and real possibilities: Paj, edhe unë do të shkoja atje, po të më ftojë/ftonte. Prandaj, le ta shohim... "Well, I would go there, if he invites me/invited me. So, let's see...." Therefore, in conditional constructions this form can shift in time, it can also express past time reference, which is expected, since its main function is to express future in the past; finally, it can also express future time reference.

On the basis of the conducted analysis, it has been noticed that $d o+$ subjunctive is characterized by a modal polysemy: it appears as epistemic, as dynamic, and as deontic. In addition to these uses, do + subjunctive can also be used in conditional apodosis and protasis. This modal polysemy is illustrated in the following figure:

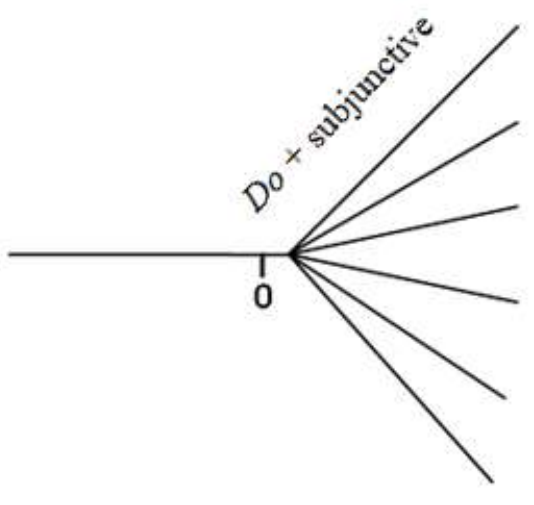

prediction (future)

assumptive conclusion (epistemic)

volition (dynamic)

order (deontic)

permission (deontic)

conditional

Figure 1. The use of $d o+$ subjunctive 


\section{Conclusions}

Based on the results it can be concluded that:

- $d o+$ subjunctive form, in most of the cases, is used to mark the epistemic future (irrealis) in Albanian language;

- the use of $d o+$ subjunctive in clear modal function is not completely peripheral, as it is found in $18.47 \%$ of the cases;

- studies on $d o+$ subjunctive should be done in a broader context in order to achieve more accurate results. If the grammatical form $d o+$ subjunctive is seen in its primary function only, then the modal meanings that it expresses in certain contexts would not be easily identified.

\section{References}

Albanian National Corpus. (2019, June 17). Retrived from http://webcorpora.net/AlbanianCorpus/search/?interface_language $=\mathrm{sq}$

ASHSH (2002). Gramatika I. Tiranë, Albania: Akademia e Shkencave dhe e Arteve e Shqipërisë.

Fehmiu, B. (2016). Shkëlqim dhe tmerr. Beograd, Srbia: Samizdat B92.

Fehmiu, B. (2011). E shklqyeshme dhe e tmerrshme. Prishtina, Kosovo: Koha Ditore.

Bokshi, B. (2012). Format e futurit të shqipes në raport me gjuhët e Ballkanit. In R. Ismajli (Eds.), Shqipja dhe gjuhët e Ballkanit (pp. 29 - 36). Prishtinë, Kosovo: Akademia e Shkencave dhe e Arteve e Kosovës.

Breu, W. (2010). Mood in Albanian. In B. Rothstein, R. Thieroff (Eds). Mood in the languages of Europe (pp. 447 - 472). Amsterdam/Philadelphia, Netherlands/Pennsylvania: John Benjamins Publishing Company.

Bybee, J. L., Perkins, R., \& Pagliuca, W. (1994). The Evolution of Grammar, Tense, Aspect and Modality in the Languages of the World. Chicago/London, Illinois/ England: The University of Chicago Press.

Camaj, M. (1984). Albanian Grammar. Wiesbaden, Germany: Otto Harrassowitz.

Demiraj, Sh. (1988). Gramatika historike e gjuhës shqipe. Tiranë, Albania: Akademia e Shkencave e Shqipërisë, Instituti i Gjuhësisë dhe i Letërsisë.

Demiraj, Sh. (2002). Gramatika historike e gjuhës shqipe. Tiranë, Albania: Akademia e Shkencave e Shqipërisë, Instituti i Gjuhësisë dhe i Letërsisë.

Huddleston, R., Pullum, G. K. (2002) Grammar of the English Language. Cambridge, England: Cambridge University Press.

Koha Ditore. (2012, December 18). Prishtinë, Kosovo: Koha.

Lyons, J. (2001). Hyrje në gjuhësinë teorike. Tiranë, Albania: Dituria.

Palmer, R. F. (2001). Mood and Modality. Second Edition. Cambridge, England: Cambridge University Press.

Topalli, K. (2012). Gramatika historike e gjuhës shqipe. Tiranë, Albania: Akademia e Shkencave të Shqipërisë. 


\section{Arnavutça'da do+dilek kipi, gelecek zaman göndergesi ve kiplik}

$\ddot{O} \mathbf{z}$

Bu çalışmanın amacı, Arnavutça'da gelecek zamanı belirleyen bir dilbilgisel öge olarak do+ dilek kipinin kullanımını ele almaktır. Bahsekonu dilbilgisel öge, dua+dilek kipi serbest sözdizimsel yapısından ortaya çıkıp bir zamanlar dilek ve istek kipini ifade etmek için kullanılırdı. Dolayısıyla, Arnavutça'da do+dilek kipi istek-in (voluntifi) gelecek zamanı olarak tanımlanır. Gelecek zamanı ifade etme işlevinin yanısıra, $d o+$ dilek kipi açık bir kip içeriğini ifade etme işlevinde için de kullanılır. do+dilek kipi şeklinin bir özelliği olan bu kip içeriği, bulunduğu bağlama göre farklı şekillerde okunabilir. Bir bilgi kipliği (epistemic modality) ifade edebiliyorken, aynı zamanda, konuşmacının genel bilgisi ve tecrübelerine de dayanabilir. Yine, bu dilbilgisel unsur, emir veya söz verme gibi farklı şekilleriyle yükümlülük kipliği (deontic modality) işlevinde de bulunabilir. Çok sık olmasa da, do+dilek kipi konuşmacının iradesini veya isteğini ifade etmek için kullanılır. Bu kiplik özelliği, özellikle, do+ geçmiş zamanlıdilek kipinde (ör. do të punoja) görülmektedir. Sözü geçen kullanımların yanısıra, gerçek ve gerçek olmayan şartları ifade etmek amacıyla şart kipi yapılarında, sonuç ve koşul yan tümceciklerinde (apodosis\& protasis) de kullanılmaktadır.

Anahtar sözcükler: gelecek zamankipi; zaman; kiplik; bilgikipliği; yükümlülükkipliği; dinamik; şart

\section{AUTHOR BIODATA}

Ardita Berisha is a teaching assistant at University of Prishtina "Hasan Prishtina". Actually she is Secretary of Department of Albanian Language in the Faculty of Philology. Last five years she has been teaching Albanian Language for foreign students in the International Seminar on Albanian Language, Literature and Culture. She is a PhD student and her main focus of research is on Grammar, Semantics and Pragmatics.

Kadire Binaj is a teaching assistant at University of Prishtina "Hasan Prishtina", Faculty of Philology, Department of Albanian Language. She is doing a PhD on Linguistics. During the period of February- July 2018, she has been for one semester as an exchange PhD student at Ca' Foscari University in Venecia, with the Erasmus+ program. From 2015- 2018 she has been the Secretary of the International Seminar on Albanian Language, Literature and Culture, at Unverity of Prishtina "Hasan Prishtina", Kosovo. Her main focus of research is on Syntax, Semantics and Pragmatics. 